\title{
SIPA1 wt Allele
}

National Cancer Institute

\section{Source}

National Cancer Institute. SIPA1 wt Allele. NCI Thesaurus. Code C52624.

Human SIPA1 wild-type allele is located in the vicinity of $11 \mathrm{q} 13$ and is approximately $75 \mathrm{~kb}$ in length. This allele, which encodes signal-induced proliferation-associated protein 1 , plays a role in cell cycle progression by promoting the activity of some members of the Ras family that are nuclear-localized. 